\title{
Chronic diarrhea with villous atrophy
}

INSERM

\section{Source}

INSERM. (1999). Orphanet: an online rare disease and orphan drug data base. Chronic diarrhea with villous atrophy. ORPHA:1670

Chronic diarrhea with villous atrophy is a rare, genetic gastroenterological disease characterized by the early onset of chronic diarrhea, vomiting, anorexia, lactic acidosis, renal insufficiency and hepatic involvement (mild elevation of liver enzymes, steatosis, hepatomegaly). Partial villous atrophy (with eosinophilic infiltration) is observed on intestinal biopsy. Although diarrhea may resolve, the development of neurologic symptoms (cerebellar ataxia, sensorineural deafness, seizures), retinitis pigmentosa and muscle weakness may complicate disease course and lead to death. There have been no further descriptions in the literature since 1994. 